\title{
Personal Entrepreneurial Competencies of Participants in Experiential Entrepreneurship Education
}

\begin{abstract}
This study aims to analyse the personal entrepreneurship competencies of students participating in experiential entrepreneurship program. In the theory part, the paper analyses the recent studies done in the entrepreneurship competencies field and discusses the experiential entrepreneurship concept. Research focuses on finding out the level of personal entrepreneurial competencies of participants of experiential entrepreneurship education, also analysing the demographic profile of the respondents, comparing it with the current job status and their entrepreneurial intentions.
\end{abstract}

Keywords: personal entrepreneurial competencies, experiential entrepreneurship education, entrepreneurial intentions.

Šiuo tyrimu siekiama paanalizuoti studentų, dalyvaujančių patyriminio verslumo programoje, asmenines verslumo kompetencijas. Straipsnio teorineje dalyje analizuojami naujausi verslumo kompetencijų tyrimai ir aptariama patirtinio verslumo samprata. Tyrimo tikslas - išsiaiškinti patirtinio verslumo ugdymo dalyvių asmeninių verslumo kompetencijų lygi, taip pat, analizuojant respondentų demografini profilį, palyginti su dabartine darbo padètimi ir jų verslumo ketinimais.

Raktiniai žodžiai: asmeninès verslumo kompetencijos, patyriminis verslumo ugdymas, verslumo ketinimai.

\section{Introduction}

During the past few decades, the importance of entrepreneurial competency has constantly increased (Alusen, 2016). Entrepreneurial competencies have been widely discussed in academic literature and they have been in the area of interest of educational institutions, also, the burst of start-ups, where entrepreneurial com- petencies are necessary is evident. According to M. L. V. Alusen (2016), attention increased not only to entrepreneurial competencies, but the human factor played by the entrepreneur himself became important as well. The significance of personal qualities, as one of the elements of entrepreneurship competencies remained relevant and under the scope of research. Thus, the object of the research

\footnotetext{
Asta KYGUOLIENE - PhD, associate professor at Marketing Department, Faculty of Economics and Management, Vytautas Magnus University, Lithuania. Address: S. Daukanto str. 28, LT-44248, Kaunas, Lithuania. Phone: +370 37 327856. Email: asta.kyguoliene@vdu.lt
}

Liudas ŠVIPAS - lecturer, Head of training programs at Entrepreneurship Academy, Vytautas Magnus University, Lithuania. Address: S. Daukanto str. 28, room 206, LT-44248, Kaunas, Lithuania. Phone: +370 677 62779. Email: liudas.svipas@vdu.lt 
is to analyse the personal entrepreneurship competencies of students participating in experiential entrepreneurship program. The research seeks to find out the level of entrepreneurial competencies of participants and compare it with other findings.

According to D. P. Depositorio, N. A. Aquino and K. C. Feliciano (2011), personal entrepreneurial competencies can be measured using PEC questionnaire, which is still widely used because of lack of reliable and more superior entrepreneurial competency measurement instruments. A research of personal entrepreneurial competencies by PEC questionnaire was done by D. Garzon (2010) researching entrepreneurs and CEOs, by N. Paladan (2015), M. L. V. Alusen (2016), G. Reyes, R. A. Mariano, M. N. Q. Herrera (2018) questioning students. There was no research done among students, taking part in experiential entrepreneurship education. The concept of experiential entrepreneurship education is still quite new and not so many study programs are organized this way, though experiential entrepreneurship education provides a vital bridge to future entrepreneurial experiences and increases entrepreneurial selfefficacy (Mandel, Noyes, 2016). Based on that research was done in order to analyse personal entrepreneurial competencies among participants of experiential entrepreneurship education from different projects. Entrepreneurship, in general, is not just a planned, intentional behaviour, it is a way of thinking (Gianesini, Cubico, Favretto, Leitao, 2018). According to that, it was assumed that participants of experiential entrepreneurship education have something in common not just in the way of thinking, but in their personal entrepreneurial competencies as well. It became interesting to research if personal entrepreneurial competencies of participants of experiential entrepreneurship education are highly expressed. Thus, the aim of this paper is to find out the level of personal entrepreneurial competencies of participants of experiential entrepreneurship education, also, to analyse the demographic profile of the respondents in terms of gender, age, comparing it with current job status and their entrepreneurial intentions.

In order to fulfil this objective, the research methods such as literature analysis, PEC questionnaire survey as the quantitative method for empirical research, data analysis were used.

\section{Personal entrepreneurial competencies}

Any competencies are defined as a cluster of related knowledge, traits, attitudes and skills that affect a major part of one's job, that correlate with performance on the job, that can be measured against well-accepted standards and that can be improved via training and development (Parry, 1998). Following this, entrepreneurial competencies have similar elements, with some differences in definition depending on scholars. According to M. P. Driessen and P. S. Zwart (2006), entrepreneurial competence consists of knowledge, motivation, capabilities and characteristics (personal qualities). T. Man and T. Chan (2002) state that entrepreneurial competencies are made up of personal attributes, knowledge and skills, M. P. Driessen (2005) - personal characteristics and skills, A. Bagheri and 
Z. A. L. Pihie (2011) - personal competencies and functional competencies, following KSA framework, entrepreneurial competencies encompass knowledge, skills and attitudes, under which personal characteristics hides (Lackeus, 2015). Each classification states that personal qualities are a part of entrepreneurial competencies, what is the object of this article.

Personal entrepreneurial competencies (PEC's) is a set of qualities, which help to outline the attitude and behaviour of entrepreneurs (Alusen, 2016). In other words, personal characteristics are traits that make people more or less capable of entrepreneurship (Driessen, Zwart, 2006). Based on scholars, personal qualities in many cases are stable and difficult to change (Driessen, Zwart, 2006), something fixed and immutable (Sanchez, 2011), comparing to capabilities, which can be developed or knowledge, which can be obtained. Broad personality traits, such as Big Five, are less related to the creation of enterprises than specific personality traits (Sanchez, 2011), so analysing the behaviour of the entrepreneur more focus should be put on specific personal traits. Certain specific attitudes and personality traits predict intention and the way new opportunities are perceived and pursuit (Krueger, Reilly, Carsrud, 2000). Among specific personal entrepreneurial competencies are named such characteristics as need for achievement, internal locus of control, risk-taking propensity, need for autonomy, need for power, tolerance of ambiguity, need for affiliation and endurance (Driessen, Zwart, 2006). According to J. C. Sanchez (2011), selfefficacy, proactiveness and inclination towards risk-taking are most linked to entrepreneurial phenomenon. A. Bagheri and Z. A. L. Pihie (2011) indicates such personal entrepreneurial competencies as pro-activeness, innovativeness and risktaking. A. Rauch and M. Frese (2007) defines 11 personality traits matched to entrepreneurship: self-efficacy, proactive personality, tenacity, need for achievement, stress tolerance, goal orientation, need for autonomy, innovativeness, endurance, flexibility and passion for work. G. Gianesini, S. Cubico, G. Favretto and J. Leitao (2018) comparing three entrepreneurial models (EntreComp, The Great Eight, 13 Entrepreneurial Competencies model) summarize personality components as tenacity, creative problem solving/imaginativeness, self-efficacy, adaptability, motivation and perseverance, though just creativity/imaginativeness and adaptability is presented in all three models.

One of the most widely used classification of personal entrepreneurial competencies was created by Management System International (MSI) and McBer and Company still in 1989. They identified 10 personal entrepreneurial competencies: opportunity seeking, persistence, commitment to work contract, risk-taking, demand for efficiency and quality, goal seeking, information seeking, systematic planning and monitoring, persuasion and networking, self-confidence. Explicit explanation of each of the personal entrepreneurial competence through the corresponding behaviour is provided in Table 1 .

According to MSI, entrepreneurial acumen can be predicted based on how strongly individuals manifest these personal entrepreneurial competencies (Reyes, Mariano, Herrera, 2018). Based on these competencies, entrepreneurial 


\section{Table 1. Corresponding behaviour of personal entrepreneurial competencies}

\begin{tabular}{|c|c|}
\hline $\begin{array}{l}\text { Personal } \\
\text { entrepreneurial } \\
\text { competencies }\end{array}$ & Corresponding behaviour \\
\hline \multirow{5}{*}{$\begin{array}{l}\text { Opportunity } \\
\text { seeking }\end{array}$} & $\begin{array}{l}\text { Being active in finding openings in the environment which can be used in different ways to } \\
\text { start a business, to create a new market or improve business operations }\end{array}$ \\
\hline & $\begin{array}{l}\text { Acting and grabbing new business opportunities even in the most problematic and hopeless } \\
\text { situations }\end{array}$ \\
\hline & Doing things before asked or forced by the events \\
\hline & Acting to extend the business to new areas, products, and services \\
\hline & $\begin{array}{l}\text { Seizing unusual opportunities to start a new business, obtain financial, equipment, land } \\
\text { workspace or assistance }\end{array}$ \\
\hline \multirow{6}{*}{ Persistence } & $\begin{array}{l}\text { Doing something continuously even though others say that you will not succeed or that you } \\
\text { are just wasting your time and effort }\end{array}$ \\
\hline & Doing something over and over again until you get what you think you deserve \\
\hline & $\begin{array}{l}\text { Standing up straight and not giving up even during the hardest times when you are trying to } \\
\text { do something new or something difficult }\end{array}$ \\
\hline & Taking action in the face of significant obstacle \\
\hline & $\begin{array}{l}\text { Taking repeated action or switching to an alternative strategy to meet a challenge or } \\
\text { overcome an obstacle }\end{array}$ \\
\hline & Taking personal responsibility for the performance necessary to achieve goals and objectives \\
\hline \multirow{6}{*}{$\begin{array}{l}\text { Commitment to } \\
\text { work contract }\end{array}$} & Giving much time and attention to something because you believe it is right and important \\
\hline & Taking full responsibility and having the job done efficiently to create a delighted customer \\
\hline & Being able to meet a deadline \\
\hline & Making a personal sacrifice or expending extraordinary effort to complete a job \\
\hline & Pitching in with workers or in their place to get a job done \\
\hline & Striving to keep customers satisfied and placing long-term goodwill over short-term gain \\
\hline \multirow{6}{*}{ Risk-taking } & Taking the chances to do something which is out of your comfort zone \\
\hline & Doing something that can result in anything unpleasant or dangerous \\
\hline & $\begin{array}{l}\text { Taking risk at any of risk-taking behaviour: from high risk-taking or moderate risk-taking to } \\
\text { low risk-taking }\end{array}$ \\
\hline & Deliberately calculating risks and evaluating alternatives \\
\hline & Taking action to reduce risks or controlling outcomes \\
\hline & Placing self in situations involving a challenge or moderate risk \\
\hline \multirow{6}{*}{$\begin{array}{l}\text { Demand for } \\
\text { efficiency and } \\
\text { quality }\end{array}$} & Demanding quality and efficiency not only from himself but also from workers and suppliers \\
\hline & Giving quality products and the best services to customers that equates to a good business \\
\hline & Working without errors and without wasting the time, money and energy \\
\hline & Finding ways to do things better, faster or cheaper \\
\hline & Acting to do thing that meet or exceed standards of excellence \\
\hline & $\begin{array}{l}\text { Developing or using procedures to ensure that work is completed on time or that work meets } \\
\text { agreed-upon standards and quality }\end{array}$ \\
\hline
\end{tabular}




\begin{tabular}{|c|c|}
\hline $\begin{array}{l}\text { Personal } \\
\text { entrepreneurial } \\
\text { competencies }\end{array}$ & Corresponding behaviour \\
\hline \multirow{4}{*}{ Goal seeking } & Planning every action and carefully making decisions based on where he wants to go \\
\hline & Setting goals and objectives that are personally meaningful and challenging \\
\hline & Articulating clear and specific long-range goals \\
\hline & Setting measurable short-term objectives \\
\hline \multirow{5}{*}{$\begin{array}{l}\text { Information } \\
\text { seeking }\end{array}$} & $\begin{array}{l}\text { Gathering information from relevant resources, which is critical to the formulation of } \\
\text { different business strategies }\end{array}$ \\
\hline & Seeking direct response, feedback \\
\hline & Personally, seeking information from clients, suppliers or competitors \\
\hline & Doing personal research on how to provide product or service \\
\hline & Consulting experts for business or technical advice \\
\hline \multirow{3}{*}{$\begin{array}{l}\text { Systematic } \\
\text { planning and } \\
\text { monitoring }\end{array}$} & Planning by breaking large tasks down into time-constrained sub-tasks \\
\hline & Revising plans in light of feedback on performance or changing circumstances \\
\hline & Keeping financial records and using them to make business decisions \\
\hline \multirow{3}{*}{$\begin{array}{l}\text { Persuasion and } \\
\text { networking }\end{array}$} & Using deliberate strategies to influence or persuade others \\
\hline & Using key people as agents to accomplish own objectives \\
\hline & Acting to develop and maintain business contracts \\
\hline \multirow{6}{*}{ Self-confidence } & Trusting his own skills and embracing his own imperfections \\
\hline & Completing any task or activity easier because of self-awareness and faith in personal abilities \\
\hline & Solid self-belief \\
\hline & Seeking autonomy from the rules or control of others \\
\hline & Striking with own judgment in the face of opposition or early lack of success \\
\hline & Expressing confidence in own ability to complete a difficult task or meet a challenge \\
\hline
\end{tabular}

Source: D. Garzon (2010), M. L. V. Alusen (2016).

competency measurement instrument was developed, which according to D. P. Depositorio, N. A. Aquino, K. C. Feliciano (2011), is widely still used because of lack of reliable and more superior entrepreneurial competency measurement instruments.

\section{Experiential entrepreneurship education concept}

Entrepreneurship education is a complex concept. The complexity of entrepre- neurship education may be understood through the range of scholar's discussions. Entrepreneurship education can be analysed as educating about, for and through entrepreneurship (Jamieson, 1984). Trying to give understanding what entrepreneurship is, how to set up and manage business reflects category of teaching about entrepreneurship, aiming at giving the requisite knowledge and skills necessary to start and manage business - category of teaching for entrepreneurship, organizing entrepreneurial learning process experientially - category of teaching 
through entrepreneurship (Lackeus, 2015; Komarkova, Gagliardi, Conrads, Collado, 2015). Each of these categories can be analysed independently, but as well all these categories are highly interconnected, especially teaching for and through entrepreneurship when knowledge and skills can be obtained teaching experientially.

Entrepreneurship education is the process of professional application of knowledge, attitude, skills, and competencies, it is not just teaching how to become independent business owner, it is much more - entrepreneurship education encompass creating and nurturing a learning environment that promotes entrepreneurial traits and behaviours, such as becoming creative and independent thinker, risk-taker, assuming responsibility, and valuing diversity (Gautam, Singh, 2015). According to A. Gibb (2000), entrepreneurship education needs to move away from emphasis on functional subject matter to the development of behaviours, skills and attributes better adapted to the entrepreneurial "way of life". Besides, learning from experience is regarded to be of great importance for entrepreneurs (Vinig, Souren, 2007). H. Neck, P. Greene and C. Brush (2014) state that entrepreneurship should have as a portfolio of practices, including practices of play, empathy, creation, experimentation and reflection, this way directing to experiential entrepreneurship education. Thus, in experiential entrepreneurship education, the process is the point, students are pushed out of their comfort zone to cultivate an entrepreneurial mindset as well as entrepreneurial abilities. Articulating and testing assumptions, experiencing a creation process, prototyping and experimentation in markets are essential for experiential entrepreneurship education (Mandel, Noyes, 2016). Participants of experiential entrepreneurship education are facing uncertainty and ambiguity, dealing with social complexity of interacting with potential or real customers and suppliers, demonstrating proactiveness in exploring and defining entrepreneurial opportunities. Experiential entrepreneurship education is based on lived experiences in contrast to taught, imagined or anticipated scenarios (Mandel, Noyes, 2016).

\section{Methodology of the research}

PEC questionnaire was chosen to achieve the aim of the research. The PEC questionnaire is composed of 55 statements. Each of the statement had to be rated from 1 (never) to 5 (always). The scores of entrepreneurial competencies have been counted for each respondent. According to the methodology of the research, for those respondents, who were overestimating themselves, the correction factor was used for 2 respondents. Based on the scores, the level of personal entrepreneurial competencies of participants of entrepreneurship education was determined. D. P. Depositorio, N. A. Aquino, K. C. Feliciano (2011) states that scores 19 and up indicates strong, 16-18 scores - moderate, 15 and below - weak PEC level (the highest score is 25). In addition, few questions were asked: 1. Entrepreneurial intentions in 5 years' time - if the respondent plans to establish business or has intentions to work as a specialist in a company. 2. Current respondent job/study status and few demographic questions such as gender, age. The survey was delivered online in 2019 August and spread among students 
Table 2. Demographic profile of $\mathbf{1 0 1}$ students-respondents enrolled in experiential entrepreneurship education program

\begin{tabular}{|c|c|c|c|c|}
\hline Gender & Item & Frequency & Percent & Cumulative Percent \\
\hline \multirow{7}{*}{ Age } & Women & 62 & 61.4 & 61.4 \\
\cline { 2 - 5 } & Men & 39 & 38.6 & 100.0 \\
\cline { 2 - 5 } & Total & 101 & 100.0 & \\
\hline & Item & Frequency & Percent & Cumulative Percent \\
\hline & $18-20$ & 18 & 17.8 & 17.8 \\
\hline & $21-24$ & 60 & 59.4 & 77.2 \\
\hline & $25-30$ & 12 & 11.9 & 100.0 \\
\hline & $31-99$ & 11 & 10.9 & \\
\hline
\end{tabular}

and alumni of experiential entrepreneurship education program in Vytautas Magnus University Centre "Entrepreneurship Academy". Pearson test was used to analyse scale variables correlation, nonparametric t-test was used for analysis between groups and PEC scores were analysed by means after recoding them accordingly. Data reliability test for 10 PEC components were used, Cronbach's Alpha showing 0,693 . Data was analysed by SPSS Statistics 23.

\section{Description of the respondents}

The respondents of the study are students that participated in an experiential entrepreneurship education program at least 6 months to 1,5 years and is either working as specialist in a company, has established business or is still studying. experiential entrepreneurship education program is delivered by Vytautas Magnus University Centre for Enterprise practices. Centre focuses on experience-based entrepreneurship learning, using innovative didactic methods. In university courses are delivered as minor study program "Entrepreneurship Academy". Centre together with 80 companies and 30 lecturers works with around 300 students, pupils annually. Table 2 shows the demographic profile of respondents, a number of women is bigger than men, but not highly outnumbered. The age of participants may vary from 1899 , but most of them are 18-25 years old.

\section{Research results}

Through this research we aim to find out the level of personal entrepreneurial competencies of participants of experiential entrepreneurship education, also compare how these competencies are distributed between respondents with different entrepreneurial intentions and current job status. Table 3 shows the current respondent job/study status after he has finished the experiential entrepreneurship education program. As seen in table $32,7 \%$ after graduation is working as specialists in companies and $24,8 \%$ 
Table 3. Current respondent job/study status and entrepreneurial intentions to start and run business in 5 years

\begin{tabular}{|c|c|c|c|c|}
\hline \multirow{4}{*}{ Item } & Question & Frequency & Percent & $\begin{array}{c}\text { Cumulative } \\
\text { Percent }\end{array}$ \\
\hline \multirow{4}{*}{ Job status } & Work as a specialist in a company & 33 & 32.7 & 32.7 \\
\cline { 2 - 5 } & $\begin{array}{c}\text { Have established business and } \\
\text { work there }\end{array}$ & 25 & 24.8 & 57.4 \\
\cline { 2 - 5 } & Still studying & 43 & 42.6 & 100.0 \\
\cline { 2 - 5 } & Total & 101 & 100.0 & 46,5 \\
\hline \multirow{3}{*}{$\begin{array}{c}\text { Entrepreneurial } \\
\text { intentions in } \\
\mathbf{5} \text { years }\end{array}$} & $\begin{array}{c}\text { To work as a specialist in a } \\
\text { company/government/NGO }\end{array}$ & 47 & 46,5 & 100 \\
\cline { 2 - 5 } & $\begin{array}{c}\text { Establish a business and work for } \\
\text { himself }\end{array}$ & 54 & 53,5 & \\
\cline { 2 - 5 } & Total & 101 & 100 & \\
\hline
\end{tabular}

have established business, which is an extremely high number considering regional statistics. This can be explained by that, student who enrol in entrepreneurship education program already has ideas or intentions to start their own business initiatives. When respondents were asked about their entrepreneurial intentions, either their wish to establish business or plan to work as a specialist, results divide almost equally across groups - $54 \%$ of respondents have intentions to start business in not distant future. Further research results will be analysed between these respondent groups.

Table 4 shows how PEC scores are distributed among two respondent groups: 1. Has intentions to work as specialist, 2. Has intentions to establish and run business. Both respondent groups have overall moderate personal entrepreneurial competencies. Students who have Entrepreneurial Intentions to establish and run business compared to other group stands out with strong competencies in Persistence, Goal Setting, Information Seeking and Self Confidence. Weakest Entrepreneurial Competencies were Persuasion and Networking, Demand for Efficiency and Quality, Opportunity seeking. Comparing these results with other studies we see that other authors also found Opportunity seeking as the weakest competence.

The study of R. S. Bautista, M. J. P. Barlis and A. G. Nazario (2007) focused on the levels of entrepreneurial competencies of entrepreneurs from Dagupan, Baguio, and San Fernando, with the inclusion of selected entrepreneurship students from Cordillera Administrative Region (CAR) in the Philippines. Competencies measured were Opportunity Seeking, Persistence, Commitment to Work Contract, Demand for Quality and Efficiency, RiskTaking, Goal Setting, Information-Seeking, Systematic Planning and Monitoring, Persuasion, and Self-Confidence. Opportunity seeking, risk-taking, and self-confidence are the students' weaknesses based on the study, while entrepreneurs' weakest competency is risk-taking. Generally, differences in school, age, gender and year 
Table 4. Personal entrepreneurial competencies and entrepreneurial intentions averages

\begin{tabular}{|c|c|c|c|c|c|c|}
\hline $\begin{array}{c}\text { Personal } \\
\text { Entrepreneurial } \\
\text { Competencies }\end{array}$ & $\begin{array}{c}\text { Entrepreneurial } \\
\text { Intentions in } \\
5 \text { years }\end{array}$ & $\mathbf{N}$ & Mean & Interpretation & $\begin{array}{c}\text { Std. } \\
\text { Deviation }\end{array}$ & $\begin{array}{l}\text { Std. Error } \\
\text { Mean }\end{array}$ \\
\hline \multirow{2}{*}{$\begin{array}{l}\text { Opportunity } \\
\text { Seeking }\end{array}$} & 1. Work as specialist & 47 & 16.5957 & Moderate & 2.80264 & .40881 \\
\hline & 2. Start a business & 54 & 17.1852 & Moderate & 2.19840 & .29917 \\
\hline \multirow{2}{*}{ Persistence } & 1. Work as specialist & 47 & 18.5532 & Moderate & 1.93153 & .28174 \\
\hline & 2. Start a business & 54 & 20.5556 & Strong & 2.50785 & .34128 \\
\hline \multirow{2}{*}{$\begin{array}{l}\text { Commitment to } \\
\text { Work Contract }\end{array}$} & 1. Work as specialist & 47 & 18.1915 & Moderate & 1.96312 & .28635 \\
\hline & 2. Start a business & 54 & 18.4630 & Moderate & 2.39270 & .32561 \\
\hline \multirow{2}{*}{$\begin{array}{l}\text { Demand for } \\
\text { Efficiency and } \\
\text { Quality }\end{array}$} & 1. Work as specialist & 47 & 16.8936 & Moderate & 2.18924 & .31933 \\
\hline & 2. Start a business & 54 & 17.3889 & Moderate & 2.60201 & .35409 \\
\hline \multirow{2}{*}{ Risk Taking } & 1. Work as specialist & 47 & 17.3617 & Moderate & 2.16117 & .31524 \\
\hline & 2. Start a business & 54 & 17.4444 & Moderate & 2.26263 & .30791 \\
\hline \multirow{2}{*}{ Goal Setting } & 1. Work as specialist & 47 & 16.9787 & Moderate & 2.19178 & .31970 \\
\hline & 2. Start a business & 54 & 21.2407 & Strong & 2.93923 & .39998 \\
\hline \multirow{2}{*}{$\begin{array}{l}\text { Information } \\
\text { Seeking }\end{array}$} & 1. Work as specialist & 46 & 18.8696 & Moderate & 3.22909 & .47610 \\
\hline & 2. Start a business & 54 & 19.3148 & Strong & 2.77335 & .37741 \\
\hline \multirow{2}{*}{$\begin{array}{l}\text { Systematic } \\
\text { Planning and } \\
\text { Monitoring }\end{array}$} & 1. Work as specialist & 47 & 17.2340 & Moderate & 2.29567 & .33486 \\
\hline & 2. Start a business & 54 & 18.9074 & Moderate & 2.37335 & .32297 \\
\hline \multirow{2}{*}{$\begin{array}{l}\text { Persuasion and } \\
\text { Networking }\end{array}$} & 1. Work as specialist & 47 & 15.9149 & Weak & 2.66890 & .38930 \\
\hline & 2. Start a business & 54 & 16.9259 & Moderate & 2.93227 & .39903 \\
\hline \multirow{2}{*}{ Self Confidence } & 1. Work as specialist & 47 & 16.9787 & Moderate & 3.67417 & .53593 \\
\hline & 2. Start a business & 54 & 19.5370 & Strong & 3.15459 & .42929 \\
\hline
\end{tabular}

do not significantly affect the abilities of students. The study's recommendation includes the review of each university's curriculum so as to enhance the ability of the students when seeking opportunities, taking risks and building confidence.

Table 5 analyses Entrepreneurial Competencies by comparing two groups: 
Table 5. Personal Entrepreneurial Competencies and Entrepreneurial Intentions, t-test results

\begin{tabular}{|c|c|c|c|c|c|c|c|}
\hline \multirow{3}{*}{$\begin{array}{c}\text { Personal } \\
\text { Entrepreneurial } \\
\text { Competencies }\end{array}$} & \multicolumn{2}{|c|}{$\begin{array}{c}\text { Levene's Test for } \\
\text { Equality of Variances }\end{array}$} & \multicolumn{5}{|c|}{ t-test for Equality of Means } \\
\hline & \multirow[t]{2}{*}{$\mathbf{F}$} & \multirow[t]{2}{*}{ Sig. } & \multirow[t]{2}{*}{$\begin{array}{c}\text { Sig. } \\
\text { (2-tailed) }\end{array}$} & \multirow[t]{2}{*}{$\begin{array}{c}\text { Mean } \\
\text { Difference }\end{array}$} & \multirow[t]{2}{*}{$\begin{array}{l}\text { Std. Error } \\
\text { Difference }\end{array}$} & \multicolumn{2}{|c|}{$\begin{array}{l}\text { 95\% Confidence } \\
\text { Interval of the } \\
\text { Difference }\end{array}$} \\
\hline & & & & & & Lower & Upper \\
\hline \multirow{2}{*}{$\begin{array}{l}\text { Opportunity } \\
\text { Seeking }\end{array}$} & 1.984 & .162 & .240 & -.58944 & .49820 & -1.57798 & .39910 \\
\hline & & & .248 & -.58944 & .50658 & -1.59635 & .41747 \\
\hline \multirow{2}{*}{ Persistence } & 5.361 & .023 & .000 & -2.00236 & .45053 & -2.89631 & -1.10842 \\
\hline & & & .000 & -2.00236 & .44255 & -2.88063 & -1.12410 \\
\hline \multirow{2}{*}{$\begin{array}{l}\text { Commitment to } \\
\text { Work Contract }\end{array}$} & 1.039 & .311 & .538 & -.27147 & .43958 & -1.14369 & .60074 \\
\hline & & & .533 & -.27147 & .43361 & -1.13188 & .58893 \\
\hline \multirow{2}{*}{$\begin{array}{c}\text { Demand for } \\
\text { Efficiency and } \\
\text { Quality }\end{array}$} & 2.057 & .155 & .307 & -.49527 & .48256 & -1.45277 & .46223 \\
\hline & & & .301 & -.49527 & .47682 & -1.44139 & .45085 \\
\hline \multirow{2}{*}{ Risk Taking } & .451 & .503 & .852 & -.08274 & .44208 & -.95992 & .79443 \\
\hline & & & .851 & -.08274 & .44066 & -.95720 & .79172 \\
\hline \multirow{2}{*}{ Goal Setting } & 4.378 & .039 & .000 & -4.26202 & .52238 & -5.29853 & -3.22551 \\
\hline & & & .000 & -4.26202 & .51205 & -5.27831 & -3.24572 \\
\hline \multirow{2}{*}{$\begin{array}{l}\text { Information } \\
\text { Seeking }\end{array}$} & 1.083 & .300 & .460 & -.44525 & .60017 & -1.63628 & .74578 \\
\hline & & & .466 & -.44525 & .60754 & -1.65236 & .76186 \\
\hline \multirow{2}{*}{$\begin{array}{l}\text { Systematic } \\
\text { Planning and } \\
\text { Monitoring }\end{array}$} & .046 & .831 & .001 & -1.67336 & .46632 & -2.59864 & -.74809 \\
\hline & & & .001 & -1.67336 & .46523 & -2.59662 & -.75011 \\
\hline \multirow{2}{*}{$\begin{array}{l}\text { Persuasion and } \\
\text { Networking }\end{array}$} & .117 & .733 & .075 & -1.01103 & .56115 & -2.12448 & .10241 \\
\hline & & & .073 & -1.01103 & .55748 & -2.11721 & .09515 \\
\hline \multirow{2}{*}{ Self Confidence } & .517 & .474 & .000 & -2.55831 & .67943 & -3.90645 & -1.21018 \\
\hline & & & .000 & -2.55831 & .68667 & -3.92222 & -1.19440 \\
\hline
\end{tabular}

1. Has intentions to work as a specialist; 2. Has intentions to establish and run business. T-test scores show that there is a significant difference between PEC of respondents who has intentions to establish and run business and those who don't. Students who have finished the Experiential Entrepreneurship Education program and have intentions to start a business, tend to have stronger Persistence, Goal Setting, Systematic Planning and Monitoring, Self Confidence competencies. G. U. Reyes, R. A. Mariano and M. N. Q. Herrera (2018) found that Persistence correlated with entrepreneurial intention five years after graduation. G. U. Reyes discusses that this could be interpreted that perhaps those possessing 
Table 6. Correlations between personal entrepreneurial competencies

\begin{tabular}{|c|c|c|c|c|c|c|c|c|c|c|c|}
\hline & & 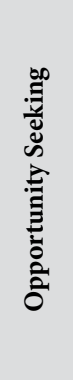 & 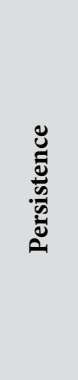 & 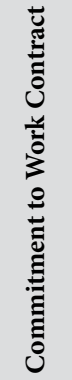 & 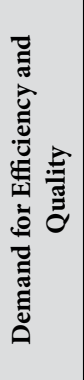 & 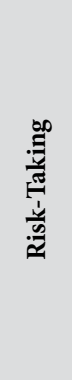 & 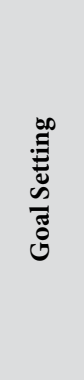 & 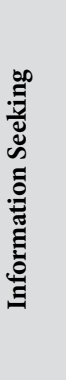 & 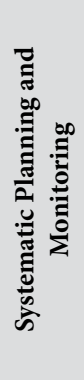 & 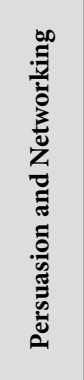 & 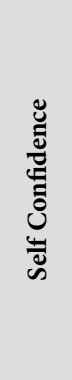 \\
\hline Persistence & $\begin{array}{l}\text { Pearson } \\
\text { Correlation }\end{array}$ & $.251^{*}$ & 1 & $.246^{*}$ & $.242^{*}$ & $.218^{*}$ & $.363^{* *}$ & .108 & $.287^{* *}$ & .089 & $.263^{* *}$ \\
\hline & Sig. (2-tailed) & .011 & & .013 & .015 & .028 & .000 & .283 & .004 & .376 & .008 \\
\hline & $\mathrm{N}$ & 101 & 101 & 101 & 101 & 101 & 101 & 100 & 101 & 101 & 101 \\
\hline Self & $\begin{array}{l}\text { Pearson } \\
\text { Correlation }\end{array}$ & .181 & $.263^{* *}$ & .192 & .076 & .065 & $.349^{* *}$ & .152 & .137 & $.304^{* *}$ & 1 \\
\hline Confidence & Sig. (2-tailed) & .070 & .008 & .054 & .451 & .520 & .000 & .131 & .173 & .002 & \\
\hline & $\mathrm{N}$ & 101 & 101 & 101 & 101 & 101 & 101 & 100 & 101 & 101 & 101 \\
\hline
\end{tabular}

these competencies are open to starting a business only after they have gained some work experience.

Also, interesting findings are about Risk-taking competence which in this research has no significant connection with intentions to establish business. These findings confirm study results done by A. J. Jumamil et al. (2017) where they found that Persistence may be considered moderately and significantly correlated with entrepreneurial intentions. Persistence shows serious intention to establish and run his own business. Though authors discuss that Demand for quality and efficiency could be related to self-efficacy, the belief that he/she is in control of his/ her fate, which has been validated to be a strong predictor of entrepreneurial intention in a number of studies, we could not confirm these findings.
Study delivered by M. L. V. Alusen (2016) showed that the BSBA Management Accounting students were found to be moderate in Persistence, Systematic Planning and Monitoring, and SelfConfidence and in some groups in Goal Setting. Risk-Taking, Persuasion and Networking competencies were found to be weak among student groups.

Table 6 shows the Pearson correlation coefficient between personal entrepreneurship competencies, as we can see there are many significant correlations and various possible these findings interpretations. But mostly it is important that Personal Entrepreneurship Competencies that we found significant related to Entrepreneurial Intentions correlate with each other: 1. Persistence and Systematic Planning and monitoring; This implies that students who have strong Persistence also tend to have Systematic planning and 
Monitoring competencies. 2. Self Confidence and Goal Setting - this implies that students who tend to have stronger Goal Setting skills tend to have higher Self Confidence.

\section{Results and discussion}

Study results indicated that students of Vytautas Magnus University Centre for the Enterprise Practice experiential entrepreneurship education program have moderate and strong personal entrepreneurial competencies. Our study results are important cause it mostly confirms research results done by G. U. Reyes, R. A. Mariano, M. N. Q. Herrera (2018) and by M. L. V. Alusen (2016). Our study showed that Student from experiential education programs tend to have strong Persistence, Goal Setting, Systematic Planning and Monitoring, Self Confidence competencies. Also, there are significant correlations between these competencies itself, showing that students with higher Goal Setting competence tend to have higher Self Confidence; students who have Persistence tend to be also strong in Systematic Planning and monitoring. The study showed that students felt weakest in competencies: Risk-taking, Persuasion and Networking, Demand for Efficiency and Quality, Opportunity seeking. This also correlates with the findings done by R. S. Bautista, M. J. P. Barlis and A. G. Nazario (2007) who found that Risk-taking competencies among students are weakest. These could be important topics for experiential entrepreneurship education program to consider including into study curriculum.
To improve the personal entrepreneurial competency levels of the business students, it is recommended to the university to review the curriculum for a business degree program that will encourage entrepreneurship and uphold more active learning, internship, fieldwork, and establishing mini-enterprise managed by the students. Also, the university could encourage students to work out activities designed to simulate actual-world situations and motivate students to organize ocular visits to small-medium enterprises, forums or symposia, trade fairs and exhibits that will develop their initiative. Program should not only focus on educating about the importance of entrepreneurship competences but also invest in more innovative, untypical and practical experiential learning methods in order to influence students' competencies, values and beliefs. Previous research postulates that entrepreneurship is both the art and the science (Westhead et al., 2011).

These personal entrepreneurship competencies are an important factor to have intentions to start own business. Though it was interesting to analyse students' entrepreneurial intentions, which showed that students who have intend to establish and run business compared to other group stands out with strong competencies in Persistence, Goal Setting, Information Seeking and Self Confidence competencies. This confirms recent findings done by A. J. Jumamil et al. (2017) where they found that Persistence may be considered moderately and significantly correlated with entrepreneurial intentions. Persistence shows serious intention to establish and run his own business. The authors also discuss that Demand for Quality and Efficiency could be related to self-efficacy, 
the belief that he/she is in control of his/ her fate, which has been validated to be a strong predictor of entrepreneurial intention in a number of studies, we couldn't confirm these findings.

It is further recommended that these core entrepreneurship competencies be continually inculcated on the students. More attention should be given to those competencies that have a more significant relationship with entrepreneurial intention. Additional statistical analysis, not included in research, showed that there were no significant difference analysing data through factors as gender, age, current job status. This was mostly a common case in other our mentioned studies and we consider it unusual finding worth further research why demographic factors are irrelevant.
The study has limitations as cause correlation and PEC scores do not show any causation factor and researches lacked a more extended list of scale variables to compare. It is suggested that other statistical methods that could establish causation should be created and used in the future. Since the students' environment was not controlled, the students may have also been influenced by other factors surrounding them at the time of research which may have affected the way they felt about themselves. In the future, research on experiential entrepreneurship education programs and personal entrepreneurial competencies should be delivered, considering inclusion of pre-tests, causation, and different demographic factors.

\section{References}

1. Alusen, M. L. V. (2016). Personal Entrepreneurial Competencies of LPULaguna BSBA Graduating Students: Basis for Curriculum Enhancement // LPU - Laguna Journal of Multidisciplinary Research. Vol. 4, No. 4, pp. 92-105.

2. Bagheri, A., Pihie, Z. A. L. (2011) Student Entrepreneurial Leaders: Challenges and Competencies of Leading University Entrepreneurship Programs // International Journal of Business and Social Science. Vol. 2, No. 2, pp. 133-144.

3. Bautista, R. S., Barlis, M. J. P., Nazario, A. G. (2007). The Personal Entrepreneurial Competencies of BS Entrepreneurship Students of the Cordillera Administrative Region and Practicing Entrepreneurs in the Cities of Baguio, Dagupan, and San Fernando, La Union: A Comparison. // 10th National Convention on Statistics (NCS) EDSA Shangri-La Hotel October1-2, 2007. Internet access: http://www. nscb.gov.ph/ncs/10thNCS/papers/invited $\% 20$ papers/ips-06/ips06-02.pdf
4. Depositario, D. P., Aquino, N. A., Feliciano, K. C. (2011). Entrepreneurial Skill Development Needs of Potential Agri-based Technopreneurs // Journal of International Society for Southeast Asian Agricultural Sciences. Vol. 17, No. 1, pp. 106-120.

5. Driessen, M. P., Zwart, P. S. (2006). De E-Scan Ondernemerstest ter Beoordeling van Ondernemerschap // Maandblad voor Accountancy en Bedrijfseconomie. Juli/ Augustus, pp. 382-391.

6. Driessen, M. P. (2005). E-scan ondernemerstest, 's-Graveland, the Netherlands: Entrepreneur Consultancy BV.

7. Garzon, D. (2010). A Comparison of Personal Entrepreneurial Competences between Entrepreneurs and CEOs in Service Sector // Service Business. Vol. 4, pp. 289-303. doi: 10.1007/s11628-009-0090-6

8. Gautam, M. K., Singh, S. K. (2015). Entrepreneurship Education: Concept, Characteristics and Implications for Teacher Education // Shaikshik Parisamvad (An 
International Journal of Education). Vol. 5, No. 1, pp. 21-35.

9. Gianesini, G., Cubico, S., Favretto, G., Leitao, J. (2018). Entrepreneurial Competencies: Comparing and Contrasting Models and Taxonomies. In Cubico S., Favreto G., Leitao J., Cartner U. (Eds.). Entrepreneurship and the Industry Life Cycle (pp. 1332). - Springer International Publishing. doi: 10.1007/978-3-319-89336-5_2

10. Gibb, A. (2002). Creating Conducive Environments for Learning and Entrepreneurship: Living with, dealing with, Creating and Enjoying Uncertainty and Complexity // Industry and Higher Education. Vol. 16, No. 3, pp. 135-148.

11. Jamieson, I. (1984). Schools and Enterprise. In Watts, A., Moran, P. (eds.) Education for Enterprise. - Cambridge: CRAC

12. Jumamil, A. J. et al. (2017). Factors Influencing the Entrepreneurial Intentions of UPLB Agri-based Graduates. // Paper presented at the DLSU Research Congress 2017, De La Salle University, Manila, Philippines, 20-22 June.

13. Komarkova, I., Gagliardi, D., Conrads, J., Collado, A. (2015). Entrepreneurship Competence: An Overview of Existing Concepts, Policies and Initiatives. - Final report of JRC Science and Policy Reports. doi:10.2791/067979

14. Krueger, N. F., Reilly, M. D., Carsrud, A. L. (2000). Competing Models of Entrepreneurial Intentions // Journal of Business Venturing. Vol. 15, No. 5, pp. 411-432.

15. Lackeus, M. (2015). Entrepreneurship in Education. What. When. Why. How. Entrepreneurship 360 background paper.

16. Man, T., Chan, T. (2002). The Competitiveness of Small and Medium Enterprises: A Conceptualization with Focus on Entrepreneurial Competencies // Journal of Business Venturing. Vol. 17. pp. 123-142.

17. Mandel, R., Noyes, E. (2016). Survey of Experiential Entrepreneurship Education Offerings among Top Undergraduate
Entrepreneurship Programs // Education + Training. Vol. 5, No. 2, pp. 164-178. doi: 10.1108/ET-06-2014-0067

18. Neck, H., Greene, P., Brush, C. (2014). Teaching Entrepreneurship: A Practice-Based Approach. Edward Elgar, Northampton, MA.

19. Paladan, N. (2015). Business University Student Entrepreneurial Competencies: Towards Readiness for Globalization // Advances in Economics and Business. Vol. 3, No. 9, pp. 390-397. doi: 10.13189/aeb.2015.030905

20. Parry, K. (1998). Grounded Theory and Social Process: A New Direction for Leadership Research // Leadership Quarterly. Vol. 9, No. 1, pp. 85-105.

21. Rauch, A., Frese, M. (2007). Let's Put the Person Back into Entrepreneurship Research: A Metaanalysis on the Relationship between Business Owners' Personality Traits, Business Creation, and Success // European Journal of Work and Organizational Psychology. Vol. 16, No. 4, pp. 353-385.

22. Reyes, G. U., Mariano, R. A., Herrera M. N. Q. (2018). Personal Entrepreneurial Competencies and Entrepreneurial Intention of NonBusiness Students Enrolled in an Introductory Entrepreneurship Course // Journal of Economics, Management \& Agricultural Development. Vol. 4, No. 1, pp. 93-102.

23. Sanchez, J. C. (2011). University Training for Entrepreneurial Competencies: Its Impact on Intention of Venture Creation // International Entrepreneurship and Management Journal. Vol. 7, No. 2, pp. 239-254. doi: 10.1007/ s11365-010-0156-x

24. Vinig, G. T., Souren, F. G. M. (2007). Failure and Entrepreneurship: A Behavioral Perspective. Working paper, University of Amsterdam, Amsterdam.

25. Westhead, P., McElwee, G., Wright, M. (2011). Entrepreneurship: Perspectives and Cases. - Pearson.

The paper submitted: June 28, 2019

Prepared for publication: December 10, 2019 


\section{Asta KYGUOLIENĖ, Liudas ŠVIPAS \\ PATYRIMINIO VERSLUMO UGDYMO DALYVIŲ ASMENINĖS VERSLUMO KOMPETENCJOS}

\section{S a n t r a u a}

Šiuo tyrimu siekiama paanalizuoti studentų, dalyvaujančiu patyriminio verslumo programoje, asmenines verslumo kompetencijas. Straipsnio teorinëje dalyje analizuojami naujausi verslumo kompetencijų tyrimai ir aptariama patirtinio verslumo samprata. Tyrimo tikslas - išsiaiškinti patirtinio verslumo ugdymo dalyvių asmeninių verslumo kompetencijų lygi, taip pat, analizuojant respondentų demografinị profili pagal lytị, amžių, palyginti su dabartine darbo padètimi ir jų verslumo ketinimais.

Per pastaruosius kelis dešimtmečius verslumo kompetencijos svarba nuolat didejjo (Alusen, 2016). Verslumo kompetencijos, kaip švietimo įstaigų interesų sritis, buvo plačiai aptariamos akademinèje literatūroje, buvo akivaizdus pradedančių įmonių kūrimosi bumas, kai būtinos verslumo kompetencijos. Asmeninių savybių, kaip vieno iš verslumo kompetencijų elementų, reikšmè yra aktuali ir nagrinètina. Patirtinio verslumo ugdymo samprata vis dar yra gana nauja ir todèl studiju programų dar nèra daug. Verslumas apskritai nèra tik suplanuotas, apgalvotas elgesys, tai yra mąstymo būdas (Gianesini, Cubico, Favretto, Leitao, 2018). Remiantis tuo buvo daroma prielaida, kad patirtinio verslumo ugdymo dalyviai turi kažką bendro ne tik mąstymo, bet ir asmeninių verslumo kompetencijų srityse. Taigi tyrimo tikslas yra išanalizuoti studentų, dalyvaujančių patirtinio verslumo programoje, asmenines verslumo kompetencijas. Tyrime daugiausia dèmesio skiriama dalyvių verslumo kompetenciju lygiui išsiaiškinti ir palyginti su kitais elementais ir kitų autorių rezultatais.

Tyrimas parodè, kad patirtinio ugdymo programos studentai pasižymi stipriai išreikštomis atkaklumo, tikslų nusistatymo, sistemingo planavimo ir stebėsenos, pasitikejjimo savimi kompetencijomis. Be to, tarp šių kompetencijų yra reikšmingas ryšys, parodantis, kad studentai, turintys aukštesnę tikslų nusistatymo kompetenciją, paprastai labiau pasitiki savimi; atkaklesniems studentams taip pat gerai sekasi sisteminio planavimo ir stebėsenos srityse. Tyrimas parodè, kad studentams trūksta šių kompetencijų: rizikos prisiemimo, ịtakos darymo ir ryšiu mezgimo, efektyvumo ir kokybès poreikio, galimybių ieškojimo. Respondentai, ketinantys ịkurti ir užsiimti verslu, palyginti su kitomis grupèmis, išsiskiria stipriomis atkaklumo, tikslų nustatymo, informacijos ieškojimo ir pasitikejjimo savimi kompetencijomis. 